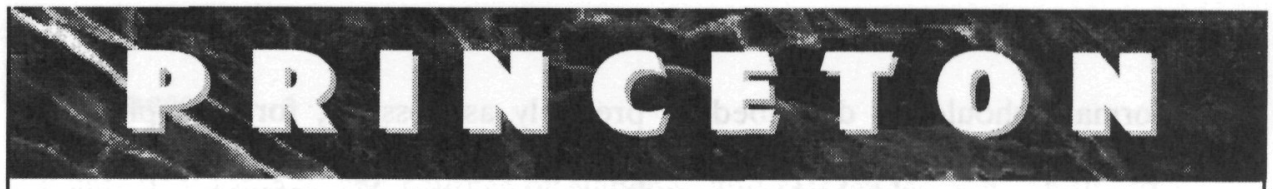

\title{
Isolationism Reconfigured
}

\section{American Foreign Policy for a New Century \\ Eric A. Nordlinger}

This iconoclastic and fundamental work, Eric Nordlinger's last, advocates a new variant of isolationism, a "national strategy" confining U.S. military actions largely to North America and to neighboring sea- and air-lanes but encouraging international activism and engagement in nonsecurity realms.

In Nordlinger's view, disengaging from security commitments on distant shores would liberate the United States to use its resources and decision-making powers to act more effectively abroad in matters of economic policy and human rights. A national strategy would then become a powerful new method of encouraging international ideals of democracy, and isolationism would be freed of its previous associations with appeasement, weakness, economic protectionism, and self-serving nationalism.

"This is a stimulating and well-argued work that will be of interest to nonacademics concerned with American foreign policy, as well as to scholars. Even those who continue to disagree with Nordlinger after reading the book will be made to rethink and deepen their own ideas."-Robert Jervis, Columbia University

Cloth: \$29.95 ISBN 0-691-04327-2

\section{The Political Economy of Democratic Transitions}

\section{Stephan Haggard and Robert R. Kaufman}

In the last two decades, there has been a widespread movement from authoritarian to democratic rule among developing countries, often occurring against a backdrop of severe economic crises and the adoption of market-oriented reforms. The coincidence of these events raises long-standing questions about the relationship between economic and political change.

In this book, Stephan Haggard and Robert Kaufman explore that relationship, addressing a variety of questions: What role have economic crises played in the current wave of political liberalization and democratization? Can new democracies manage the daunting political challenges posed by economic reform? Drawing on contemporary political economy and the experiences of twelve Latin American and Asian countries, they develop a new approach to understanding democratic transitions.

"This impressive book ... provides a trenchant assessment of the economic problems faced by new democracies and of how government responses are shaped by political forces and inherited institutional structures. Many readers have eagerly awaited the completion of this project, and they will have much to learn from the book."-David Collier, University of California, Berkeley

Paper: \$19.95 ISBN 0-691-02775-7 Cloth: \$59.50 ISBN 0-691-02974-1 


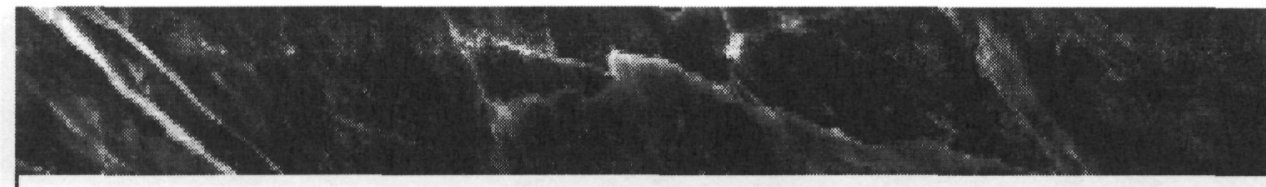

\section{Cooperation among Democracies}

The European Influence on U.S. Foreign Policy

\section{Thomas Risse-Kappen}

In exploring the special nature of alliances among democracies, Thomas Risse-Kappen argues that the West European and Canadian allies exerted greater influence on American foreign policy during the Cold War than most analysts assume. In so doing, he challenges traditional alliance theories that emphasize strategic interactions and power-based bargaining processes.

Through detailed case studies, Risse-Kappen shows that the Europeans affected security decisions concerning vital U.S. interest during the 1950-1953 Korean war, the 1958-1963 test ban negotiations, and the 1962 Cuban missile crisis-all during a span of time in which the U.S. enjoyed undisputed economic and military supremacy in the alliance. He then situates these case studies within a theoretical framework.

The book's findings have important repercussions for the post-Cold War era in that they suggest the transatlantic security community is likely to survive the end of the Soviet threat.

"The aims of this book are ambitious, and Thomas Risse-Kappen succeeds in fulfilling them.... A serious contribution to theory on cooperation among democracies." -Bruce M. Russett, Yale University

Princeton Studies in International History and Politics

Cloth: \$35.00 ISBN 0-691-03644-6

\section{Socialist Unemployment}

\section{The Political Economy of Yugoslavia, 1945-1990}

\section{Susan L. Woodward}

In the first political analysis of unemployment in a socialist country, Susan Woodward argues that the bloody conflicts that are destroying Yugoslavia stem not so much from ancient ethnic hatreds as from the political and social divisions created by a failed socialist program to prevent capitalist joblessness.

By 1985, Yugoslavia's unemployment rate had risen to 15 percent. How was it that a labor-oriented government managed to tolerate so clear a violation of the socialist commitment to full employment? Proposing a politically based model to explain this paradox, Woodward analyzes the ideology of economic growth. Forced to balance domestic policies aimed at sustaining minimum standards of living and achieving productivity growth against the conflicting demands of the world economy and national security, the leadership inadvertently recreated the social relations of agrarian communities within a postindustrial society.

Paperback: \$19.95 ISBN 0-691-02551-7 Cloth: \$55.00 ISBN 0-691-08645-1

\section{PRINCETON UNIVERSITY PRESS}

AVAILABLE AT FINE BOOKSTORES OR DIRECTLY FROM THE PUBLISHER: 800-777-4726 WORLD WIDE WEB SITE: HTTP://AAUP.PUPRESS.PRINCETON.EDU/PUPRESS 


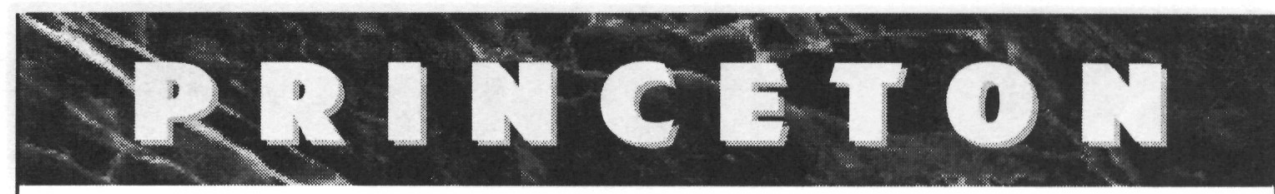

Does Conquest Pay?

The Exploitation of Occupied Industrial Societies

Peter Liberman

Can foreign invaders successfully exploit industrial economies? Since control over economic resources is a key source of power, the answer affects the likelihood of aggression and how strenuously states should counter it. Does Conquest Pay? demonstrates that expansion can, in fact, provide rewards to aggressor nations.

Peter Liberman argues that invaders can exploit industrial societies for short periods of time and can maintain control and economic performance over the long term. His work suggests that the international system is more war-prone than many optimists claim.

"This book is original, lively, important in its scope and theme, and genuinely scholarly."-Alan S. Milward, London School of Economics

Princeton Studies in International History and Politics

Cloth: \$35.00 ISBN 0-691-02986-5 Available January 1996

\section{Satellites and Commissars}

Strategy and Conflict in the Politics of Soviet-Bloc Trade Randall W. Stone

Why did the Soviet Union squander the political leverage afforded by its trade subsidy to Eastern Europe? Why did Soviet officials fail to bargain with resolve, to link subsidies to salient political issues, to make credible commitments, and to monitor the satellites' policies? Using an unprecedented array of formerly secret documents housed in archives in Moscow, Warsaw, and Prague, as well as interviews with former Communist officials across Eastern Europe, Randall Stone answers these questions and others that have long vexed Western political scientists.

"A very useful contribution to the field. ... It is very interesting and well written, and it casts new light on Eastern European and Soviet politics."

-Alec Nove, University of Glasgow

Princeton Studies in International History and Politics:

Cloth: \$35.00 ISBN 0-691-04414-7 Available February 1996

\section{Currency and Coercion}

The Political Economy of International Monetary Power

\section{Jonathan Kirshner}

Jonathan Kirshner here examines how states can-and have-used international currency relationships and arrangements as instruments of coercive power for the advancement of state security. Kirshner lays the groundwork for the study of what he calls monetary power by providing a taxonomy of the forms that such power can take and of the conditions under which it can have effect.

Integrating security studies and international political economy, this book is a timely synthesis that will be important to the entire discipline of international relations.

Cloth: \$39.50 ISBN 0-691-03768-X Available November 1995 


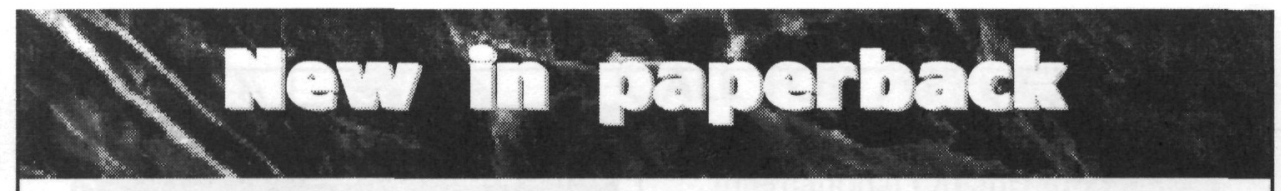

\section{Allies, Adversaries, and International Trade Joanne Gowa}

"In uniting the fields of international security and political economy, this superb book succeeds where many others have failed. Quantitative and qualitative tests give empirical bite to its spare theoretical formulation. A reader's dream, this book is both thin and big."-Peter J. Katzenstein

"An outstanding and original book."-David A. Lake

Now in paper: \$14.95 ISBN 0-691-04471-6

\section{Power, Trade, and War Edward D. Mansfield}

"A book that makes major contributions to a political-economy approach to theorizing and analyzing international relations. ... Mansfield's research is exemplary and thought-provoking. ... [ [It] generates a number of important findings. ..."

-The Annals of the American Academy of Political and Social Science Now in paper: \$17.95 ISBN 0-691-04482-1

\section{Democracy and International Trade}

\section{Britain, France, and the United States, 1860-1990}

\section{Daniel Verdier}

"This is an unusual and possibly a 'mind-changing' book. ... [It] has the potential to change many well-established perceptions about political economy and its influence on foreign policy."-International Affairs

Now in paper: \$18.95 ISBN 0-691-02103-1

Winner of the Best Book Award from the Science, Technology, and Environmental Studies Section of the American Political Science Association

\section{The Limits of Safety}

Organizations, Accidents, and Nuclear Weapons

"An extraordinary book. ..."

\section{Scott D. Sagan}

-Charles Perrow, Journal of Contingencies and Crisis Management

"Scott Sagan's book is nothing less than a tour de force. . . It is by far the most carefully researched and painstaking study of nuclear weapons safety ever written." -Bruce G. Blair, Security Studies

Princeton Studies in International History and Politics

Paper: \$14.95 ISBN 0-691-02101-5 


\section{Journal of Peace Research}

\section{Edited by Nils Petter Gleditsch and Malvern Lumsden, PRIO, Oslo}

"Journal of Peace Research successfully and creatively bridges the gap between theory and practice. It provides scholars and policymakers with theoretically sophisticated and empirically informed analyses of the most timely issues on the global security agenda. The impact on thinking and the evolution of peace studies has been substantial."

Charles W. Kegley, Jr, Past President, International Studies Association

Recent and forthcoming contents...

- Julian Cooper on Conversion is Dead, Long Live Conversion!

- Arie M. Kacowicz on Explaining Zones of Peace: Democracies as Satisfied Powers?

- Knud S. Larsen et al. on Ideology and Identity: A National Outlook

- Laura Neack on UN Peace-keeping: In the Interest of Community or Self?

- David Bloomfield on Complementarity in Conflict Management: Resolution and Settlement in Northern Ireland

- David Adams on Internal Military Intervention in the United States

- Erich Weede on Why Nations Arm: A Reconsideration

- Rhoda E. Howard: Human Rights and the Search for Community

- James Lee Ray: Global Trends, StateSpecific Factors and Regime Transitions, 1825-1993

ISSN: (0022-3433)

Published quarterly in February, May, August and November

Don't forget, we guarantee that if you are dissatisfied with your journal in any way, we will refund the cost of your subscription.
Subscribe at the introductory rate

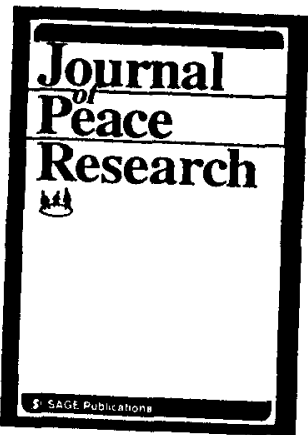

Order Form for New Subscribers

\section{SAGE Publications Ltd}

6 Bonhill Street, London EC2A 4PU, UK

Tel + $44(0) 1713740645$

Fax +44(0)171 3748741

USA orders to be sent to:

PO Box 5096, Thousand Oaks, CA 91359

Y Yes! I want to subscribe to Journal of Peace Research starting with Volume 32 (1995) at the:

Dindividual Rate for New Subscribers $£ 24 / \$ 38$ (usual rate $£ 30 / \$ 48$ )

D Institutional Rate $£ 95 / \$ 152$

\section{Methods of Payment}

口 CHEQUE... I enclose a cheque (made payable to SAGE Publications Ltd) for:

C CREDIT CARD...

Please invoice my credit card

a Mastercard $\square$ Access $\square$ Eurocard

$\square$ Diner's Club $\square$ American Express $\square$ Visa

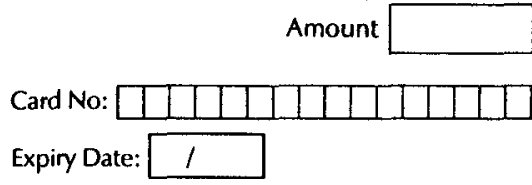

Signature: Date: / / .

Name

Address 

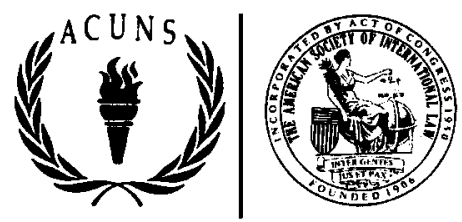

\section{Call for Applications}

1996 ACUNS/ASIL Summer Workshop on International Organization Studies

Brown University, 28 July - 9 August 1996

\section{The Role of Governmental, Intergovernmental, and Nongovernmental Institutions in Global Governance: Nurturing the Next Generation of Scholars}

\section{Purpose}

ACUNS and the American Society of International Law are jointly sponsoring the sixth in a series of summer workshops on international organization studies to be held at Brown University from 28 July to 9 August 1996. This is the first workshop designed specifically for advanced graduate students and post-doctoral scholars. The purposes of this workshop are to:

- enhance professional development in international organization studies

- encourage new directions in international organization research
- establish and strengthen contacts amongst legal and international relations scholars and UN practitioners

- stimulate teaching in international organization studies

\section{Program}

The 1996 workshop will be directed by Dorinda Dallmeyer of the University of Georgia; W. B. Ofuatey-Kodjoe of the City University of New York; and Peter Uvin of Brown University.

The focus of this year's workshop is "The Role of Governmental, Intergovernmental, and Nongovernmental Institutions in Global Governance." The workshop will serve as a forum for multidisciplinary exchange and research, and will be structured to help stimulate interest and guide advanced graduate students in the research and writing of their dissertations (or postdoctoral scholars in turning their dissertations into books and articles) related to the role of global governance.

The subject matter is open to participants whose analytical perspectives are multilateral-to those who are trying to focus on the role of state and non-state institutions in the complex task of global governance. The United Nations system is crucial in this effort; but, key insights result from how nonUN institutions can complement UN ones in a better division of labor.

\section{Application Procedure}

Completed applications must be postmarked no later than February 15,1996 . For more information and application guidelines, please contact:

ACUNS/ASIL Summer Workshop Brown University, Box 1983

Providence, RI 02912-1983

Attn: Program Assistant

Tel: 401/863-1274

Fax: $401 / 863-3808$

Funding for this workshop is provided by the Ford Foundation. 


\section{Issue Frequency}

Quarterly; Winter, Spring, Sumer, Fall

\begin{tabular}{|c|c|c|c|c|c|c|c|c|c|}
\hline \multicolumn{9}{|c|}{2 Publication Nio } & \multirow{2}{*}{$\begin{array}{l}\text { 3. Fing Oat } \\
9 / 28 / 95\end{array}$} \\
\hline 0 & 0 & 2 & 0 & - & 8 & 1 & 8 & 3 & \\
\hline
\end{tabular}

7. Complete Mailing Address of Known Oftica of Publucation (Sireet. Ciry. County. State. and ZJP+4) (Not Pnnter)

MIT Press, 55 Hayward Street, Middlesex, MA 02142-1399

8. Complate Maling Address of Meadquaners or Generat Qusiness Ottice of Puolisner (Not Pnnter)

same as item 7

9. Fuit Namas and Complete Malling Addresses of Publisher, Editor and Managing Edilor (Do Not Leave Blank)

Qublisher (Name and Complete Matieng Adoress)

MIT Press, 55 Hayward Street, Cambridge, MA 02142-1399

Edtor (Name and Complete Mating Address)

John S. Ode11, School

Managing Edilor (Name and Complate Mailing Adaress)

Candyce Kornblum Anger, School of International Relations, University of Southern

California, Los Angeles, CA 90089-0043 10. Owner (ll owmed by a conporauron, its name apo adoress must be stated and also immedrately thereatter the names and addresses of stockholders owning owned by a partnershre or other unincorporated firm, its name and address as wefl as that ol each individual must be given. If the putication is published by a nonprolit arganization, its name and address must be stated.) (Do Not Leave Glank.

\begin{tabular}{c|c}
\hline Full Name & Complete Mailing Address \\
\hline MIT Press & 55 Hayward Street, Cambridge, MA 02T42-T399 \\
\hline & \\
\hline
\end{tabular}

11. Known Boncholders. Mortgagees, and Other Securty Hotders Owning of Holding 4 Percent or More of Total Amount ol Bonds. Mongages, or Other Secunties It none check here. EX None

\begin{tabular}{c|c|c}
\hline Full Name & Complete Mailing Address \\
\hline & & \\
\hline & & \\
\hline
\end{tabular}

12. For compietion by nonproht organtzations authopized to mail at special rates The purdose tunction and nonprolit siatus of tins orgamzation and the exemp

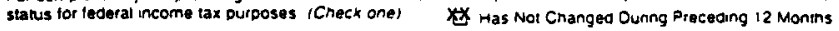

0 Mas Cnanged Ouring Preceding 12 Monins

:"l cranged. puolisner musi suomil explanation ol change with inis statement) 


\begin{tabular}{|c|c|c|}
\hline $\begin{array}{l}\text { 13. Puobcation Nam } \\
\text { IO, INTERNAT IONAL ORGANIZATION }\end{array}$ & $\begin{array}{l}14 \text { Issue Date ior Circulation Oata Bel } \\
49: 2 \text {, Spring } 1995\end{array}$ & \\
\hline Extent and Nature of Cireulation & $\begin{array}{l}\text { Average No. Copies Each tssue } \\
\text { During Preceding } 12 \text { Months }\end{array}$ & $\begin{array}{l}\text { Actual No. Copies of Single lasue } \\
\text { Published Noarest to Filing Date }\end{array}$ \\
\hline a. Total No. Copies (Net Press Run) & 3898 & 3814 \\
\hline $\begin{array}{l}\text { 0. Pavd and/or Requested Cireulation } \\
\text { (1) Sales Through Dealers and Camers. Street Vendors. and Counter Sales } \\
\text { (Nof Maited) }\end{array}$ & 77 & 77 \\
\hline $\begin{array}{l}\text { (2) Paid or Aequested Mail Subscnotions } \\
\text { (Include Advemsers' Prool Copies Exchange Copies) }\end{array}$ & 2688 & 2967 \\
\hline $\begin{array}{l}\text { c. Total Paid and/or Requested Circulation } \\
\text { (Sum of } 15 \mathrm{~b}(1) \text { and } 15 \mathrm{~b}(21)\end{array}$ & 2765 & 3044 \\
\hline $\begin{array}{l}\text { d. Free Distnbution by Mall } \\
\text { (Samples, Complimeniary, and OMner Free) }\end{array}$ & 59 & 58 \\
\hline e. Free Distribution Outside the Mail (Carners or Oiner Means) & 57 & 54 \\
\hline 1. Tolal Free Distnbution (Sum of 15d and 15e) & 116 & 122 \\
\hline 9. Total Distnbution (Sum ol $15 c$ and $15 l$ ) & 2881 & 3166 \\
\hline $\begin{array}{l}\text { n. Copies Not Distntuited } \\
\text { (1) Otfice Use. Lehovers, Spoiled }\end{array}$ & 1017 & 648 \\
\hline (2) Return Irom News Agenis & 0 & 0 \\
\hline 1. Total (Sum of 15g. $15 h(1)$, and $15 h(2)$ ) & 3898 & 3814 \\
\hline $\begin{array}{l}\text { Poreent Pard andror flequested Circuiation } \\
(15 c / 15 g \times 100)\end{array}$ & $96 \%$ & $96 \%$ \\
\hline 16. This Statement of Ownersho will oe pnnted in the $49: 4$, Fa 1195 , & we of this publication. 0 Check bo & it nol required to publish. \\
\hline 17. Signature and Title of Editor. Publisher, Ousiness Manager, or Owner & & Date \\
\hline Dative Dewereant & Circulation Manager & $9 / 28 / 95$ \\
\hline
\end{tabular}

\section{Instructions to Publishers}

1. Complete and file one copy of this form with your postmaster on or betore October 1, annually. Keep a copy of the completed torm for your records.

2. Inctude in items 10 and 11 , in cases where the stockholder or security holder is a lustee. the name of the person or corporation for whom the trustee is acting. Also include the names and addresses of individuals who are stockholders who own or hold 1 percent or more of the total amount of bonds. mongages, or other securities of the pubtishing corporation. In item 11, if none, check box. Use blank sheets if more space is required.

3. Be sure to lumish all information called for in item 15, regarding circuiation. Free circulation mus! be shown in items $15 d, e$, and 1 .

4. If the publication had second-class authorization as a general or requestef publication, this Slatement of Ownership. Management, and Circulation must be published: it must be printed in any issue in October or the lirst printed issue after Octcber. if the publication is not published during October.

5. In item 16, indicate date of the issue in which this Statement ol Ownership will be peinted.

6. Hem 17 must be signed.

Failure to file or publish a statement of ownership may lead to suspension of second-class authonzation. 


\section{The Gaza Sirip \\ The Political Economy of De-Development}

\section{Sara Roy}

In this ground-breaking and comprehensive study, Sara Roy examines in detail the political economy of the Gaza Strip since the Israeli occupation in 1967. Providing an historical context for Israeli economic policy, Roy argues that despite certain economic benefits that have accrued to the Gaza Strip as a result of its interaction with Israel, Israeli policy in the Strip has been guided by political concerns that not only hindered, but blocked internal economic development. This resulted in Gaza's de-development, a new concept defined by Roy and one she demonstrates is peculiar to Israeli rule.

Spring 1995. 350pp. + illus.

Hardcover- ISBN: 0-88728-260-1, $\$ 27.95 / £ 19.95$

Paperback - ISBN: 0-88728-261-X, \$17.95/£11.95

\section{Fallen Pillars U.S. Policy lowards Palestine and Israel since 1945}

\section{Donald Neff}

Those following the Palestinian-Israeli conflict and the current peace process are certainly aware of the important role played by the United States over the course of the conflict and in the peace-making process. At the UN, on the diplomatic front, or at the negotiating table, American foreign policy has shaped, and continues to shape, events in the region. Fallen Pillars is a concise summary of the evolution of American foreign policy towards Palestine and Israel over the past half century.

Spring 1995. 280pp + illus.

Hardcover - ISBN: 0-88728-262-8, $\$ 25.00$

Paperback - ISBN: 0-88728-259-8, \$15.00/£11.95

INSTITUTE FOR Palestine Studies

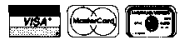

1-800-874-3614

Institute for

Palestine Studies 3501 M Street, N.W.

Washington, DC 20007

Tel. 202-342-3990

Fax 202-342-3927

$171-916-1069$

Distributed outside North America by I.B. Tauris \& Co. Ltd. 45 Bloomsbury Sq. London WC1A 2HY, UK 


\section{JOURNAL OF DEMOCRACY}

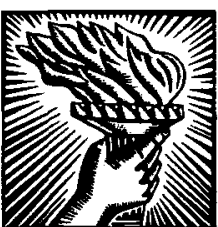

EDITORS

Marc F. Plattner

Larry Diamond

EDITORIAL BOARD

Chinua Achebe

Shaul Bakhash

Nancy Bermeo

Daniel Brumberg

Naomi Chazan

Charles H. Fairbanks, Jr

Francis Fukuyama

Harry Harding

Donald L. Horowitz

Samuel P. Huntington

Atul Kohli

Leszek Kolakowski

Liang Heng

Arend Lijphart

Juan J. Linz

Seymour Martin Lipset

Joshua Muravchik

Ergun Özbudun

Octavio $\mathbf{P}_{\mathbf{2 z}}$

Susan Kaufman Purcell

Peter Reddaway

Condoleezza Rice

Philippe Schmitter

Alfred Stepan

Vladimir Tismaneanu

Arturo Valenzucla

(on leave)

Emest J. Wilson III

(on leave) ince its inception in 1990, the Journal of Democracy has become an influential international forum for scholarly analysis and competing democratic viewpoints.

Focusing exclusively on democracy, the Journal monitors and analyzes democratic regimes and movements in scores of countries around the world. Published quarterly in January, April, July, and October for the National Endowment for Democracy.

April 1995 (Volume 6, Number 2) includes:

a. Transcending the Clash of Cultures

Democracy's Forgotten Dimension

Freedom, Development, and IIuman Worth

- Confucianism and Democracy

- Reexamining Ruissia

Crime Without Punishment

Institutions and Incentives

a The Post-Totalitarian Blues

- Strategies and Outcomes in Eastern Europe

- Constitutional Engineering in Southern Africa

- Economic Reform and Democracy

Beyond Shock Therapy

Can the Middle East Compete?

Crisis and Opportunity in Africa

The Politics of Safety Nets

Prepayment is required. Annual Subscriptions: $\$ 26.00$, individuals; $\$ 55.00$, institutions. Foreign postage: $\$ 3.80$, Canada $\&$ Mexico; $\$ 7.70$, outside North America. Single-issue prices: $\$ 8.00$, individuals; $\$ 16.00$, institutions. Payment must be drawn on a U.S. bank in U.S. dollars or made by international money order. MD residents add 5\% sales tax. For orders shipped to Canada add 7\% GST (\#124004946).

Send orders to: The Johns Hopkins University Press, P.O. Box 19966, Baltimore, MD 21211. To place an order using Visa or MasterCard, call toll-free 1-800-548-1784, FAX us at (410) 516-6968, or send Visa/MasterCard orders to this E-mail address: jlorder@jhunix.hcf.jhu.edu 


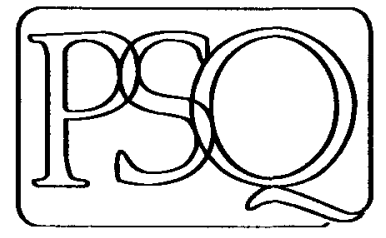

$P S Q$ is the most widely read and accessible journal of public and international affairs. Published continuously since 1886 by the Academy of Political Science, $P S Q$ presents authoritative analyses essential to understanding today's complex world.

"Most serious journals are narrow; most journals which are broad in scope are not serious. PSQ is the exception: a journal which is both broad in scope and serious in content. It is must reading for social scientists and informed citizens interested in public affairs."

SAMUEL HUNTINGTON Harvard University

\section{POLITICAL SCIENCE QUARTERLY}

$P S Q$ publishes in-depth articles on domestic and foreign affairs. Each issue contains some 35 book reviews. $P S Q$ 's editorial advisory board is composed of outstanding scholars from the nation's leading universities and think tanks.

If you haven't been reading $P S Q$, you've missed articles, book reviews and essays by world-class scholars like...

Robert Jervis • Walter LaFeber Ralph Nader • Joseph Nye

Paul Peterson • Robert Reich Arthur Schlesinger $\bullet$ Theda Skocpol William Julius Wilson

Subscribe by joining the Academy of Political Science

Name

Address

City State Zip

Telephone

$\square$ Check enclosed Charge my: $\square$ Amex $\square$ Visa $\square$ Mastercard

Card Number Expire Date

Signature

Individuals: $\square$ 1 year \$39 $\square 2$ years \$70 $\square 3$ years \$93 $\square$ Students \$24

Institution: $\square$ \$138 All subscribers outside USA add \$8/year.

The Academy of Political Science

475 Riverside Drive, Ste. 1274 / New York, NY 10115-1274 USA

TEL (212) 870-2500 / FAX (212) 870-2202 


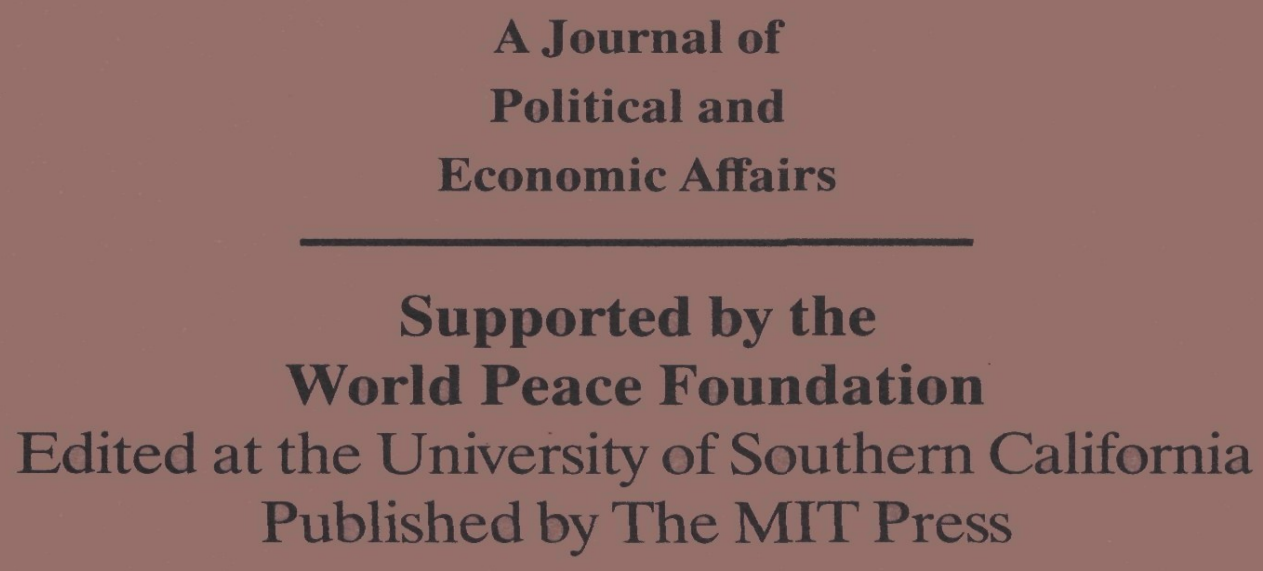

